\title{
Role of Battery Energy Storage System in Modern Electric Distribution Networks - A Review
}

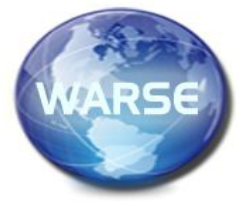

\author{
Meera Sharma $^{1}$, Parag Nijhawan ${ }^{2 *}$, Amrita Sinha $^{3}$ \\ 1,2,3 Thapar Institute of Engineering and Technology, Patiala, INDIA \\ 1taurusmeera@gmail.com \\ 2parag.nijhawan@rediffmail.com \\ 3amrita.sinha@thapar.edu
}

\begin{abstract}
The dependence on the conventional energy sources is on the decline due to their limited stocks and the pollution involved. This has resulted in the shift in the focus towards renewable energy harnessing in recent times. But there is a major limitation of these renewable sources that these are all intermittent in nature. The increase in penetration of renewable energy in various applications, due to the major focus of significant government and private initiatives has also led to the development of energy storage systems to enhance their reliability. Battery energy storage systems (BESS) is one such system. It is dedicated equipment or system which is used in renewable energy systems, and in electric power distribution networks to enhance the overall reliability and quality of power supply. In this paper, an effort has been made to compile the role of BESS in the electrical distribution systems without/with renewable energy systems in stand-alone and grid mode.
\end{abstract}

Key words: BESS, SOC (state of charge), STATCOM (static synchronous compensators), LFC (load frequency control)

\section{INTRODUCTION}

Energy storage systems such as potential energy in pumped hydro, heat energy as in molten salt, in case of flywheels as kinetic energy, compressed air energy storage (CAES), capacitors (electrical energy), batteries (electrochemical energies) form an important aspect in improving the reliability of renewable energy systems. The cost of pumped hydro is less but due to its dependability on unpredictable factors like environmental and geographical, the inclination has shifted towards energy storage systems like Battery energy storage systems (BESS) so that cleaner and sustainable energy is retained. The sporadic character of renewable energy generation adds a supplementary unpredictability to the grid systems [1].

In light of this, BESS is an essential system that can help in significantly improve this undesirable situation. The path breaking impact of BESS in the electrical power system is such that it makes the grid smarter by providing a backup option [2-3]. The role of BESS in the electrical distribution systems without/with renewable energy systems in standalone and grid mode is of utmost importance [4-5]. There can be different batteries that are used in BESS. Table 1 presents the performance parameters of four such types of batteries [6]. The sodium sulfur battery is supposed to be kept at $290 \sim 350^{\circ} \mathrm{C}$ to facilitate customary working. The worth of lithium ion battery is relatively high in comparison to other batteries. Low energy density of flow battery and phenomenon of discharging by self of Ni-MH is exceedingly sharp [7-8].

Table 1: Comparison of Batteries [3]

\begin{tabular}{|l|l|l|l|l|l|}
\hline $\begin{array}{l}\text { Battery } \\
\text { type }\end{array}$ & $\begin{array}{l}\text { Capacit } \\
\mathrm{y} \\
(\mathrm{kW})\end{array}$ & $\begin{array}{l}\text { Energy } \\
\text { density } \\
(\mathrm{Wh} / \mathrm{kg} \\
)\end{array}$ & $\begin{array}{l}\text { Life } \\
\text { span(cycle } \\
\mathrm{s})\end{array}$ & $\begin{array}{l}\text { Self } \\
\text { discharg } \\
\mathrm{e} \\
(\%)\end{array}$ & $\begin{array}{l}\text { Operatin } \\
\mathrm{g} \text { temp. } \\
(\mathrm{C})\end{array}$ \\
\hline $\begin{array}{l}\text { Sodiu } \\
\mathrm{m} \\
\text { sulfur }\end{array}$ & 100 & 100 & 2,500 & 0 & $\begin{array}{l}290 \\
350\end{array}$ \\
\hline $\begin{array}{l}\text { Lithiu } \\
\text { m ion }\end{array}$ & 200 & $90-160$ & $600-1,200$ & $6-9$ & $\begin{array}{l}(-30) \\
50\end{array}$ \\
\hline $\begin{array}{l}\text { Flow } \\
\text { batterie } \\
\mathrm{s}\end{array}$ & 10 & $30-50$ & 10,000 & 0 & $0-40$ \\
\hline Ni-MH & 100 & $60-80$ & 1,000 & $30-50$ & $-30-55$ \\
\hline
\end{tabular}

\section{ADVANCEMENTS IN BESS TECHNOLOGY}

\section{Using Super capacitor for Renewable Energy Power Generation}

Among all type of utilities, renewable energy sources are becoming more significant and environment friendly. For grabbing a big deal of attention wind generators and photovoltaic cells are competent [9]. They suggest valuable compensation for better stability, power quality and constancy of supply. Power source voltage drop results from the rapid increase of load which shall depreciate power quality. Moreover, for reaching the peak power requirement in some intense circumstances the major power source is inadequate to provide required power [10]. So, to increase the specific power and density of power sources, there is a vital need of energy storage systems. 


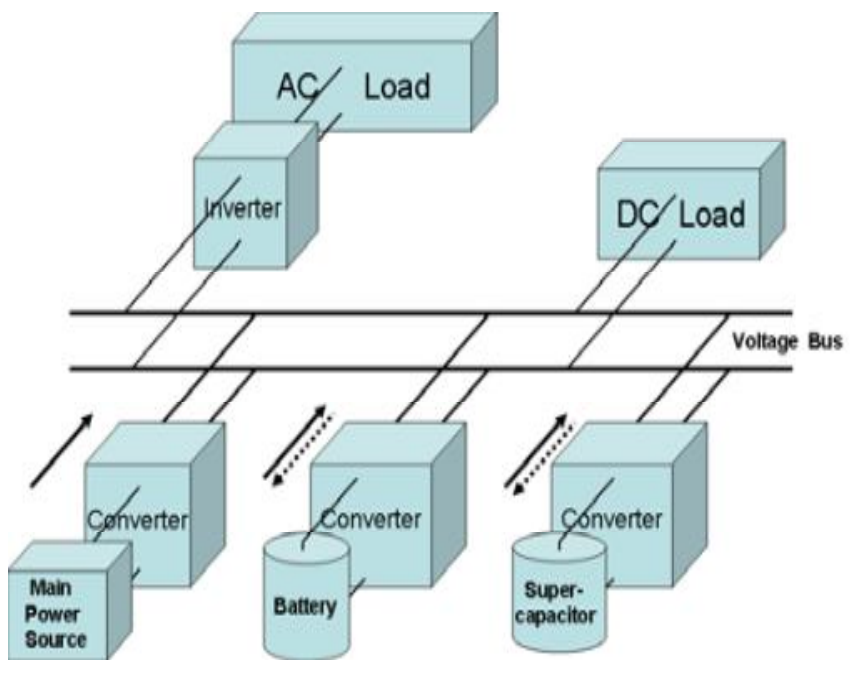

Figure 1: Architecture of super capacitor hybrid system [17]

Super capacitors have larger density of power in the form of static electronic charge as compared to battery which uses electrochemical process for achieving energy storage [1114]. On combining these two devices, as shown in figure 1, higher power output and better energy performance is found. To reimburse rapid power output changes the super capacitor is useful which is a device for short time energy storage, but to appropriately meet the energy demand, the long lasting device for storage of energy is BESS [15-18]. In terms of flexibility, active hybrids in hybrid energy storage system are more flexible than the passive hybrids in which power source and voltage bus are directly connected [16]. For dynamically controlling the power allocation in devices for energy storage in these systems, $\mathrm{dc} / \mathrm{dc}$ power converter is used for connecting each and every energy device [17-19]. Unlike pre mediated hybrid sources like fuel cells/ super capacitors, fuel cell/ battery [20-23], there is no justification for the control of active hybrid battery/ super capacitors system for energy storage [24-25].

\section{Using superconducting coil for clean generation}

The results verify that fuel cell system which don't have energy storage element cannot be made use of to start the motor. To solve this issue, an energy storage power system and a hybrid fuel cell, whether in a higher range temperature form, along with utilization of superconducting magnetic energy storage system can be suggested. The motor starting problem is solved by the hybrid system and the slow responding fuel cell system is complimented with quick operation of energy storage system. This is advantageous in terms of increasing the efficiency and fuel cell operating life.

\section{ESTIMATION OF SOC BALANCING OF BATTERY UNITS}

Even though cascade converters are being mostly studied for static synchronous compensators (STATCOMs) and motor drives [26]-[29], their characteristic structure finds it appropriate for energy storage applications based on EDLC (Electric double layer capacitor) and BESS. Battery management system (BMS) plays an essential part in the estimation of the SOC, frequently referred as the "fuel gauge" function. On the basis of certain parameters like voltage, current, and internal impedance which fluctuate with the SOC, the estimation can be made [30-31].

Tolbert et al. [32] describes working of a cascade converter by using BESS for a motor drive where voltage balance control is maintained by injecting harmonic currents [33-35].

\section{IMPROVING POWER QUALITY USING BESS}

\section{Wave energy conversion (WEC) system}

For smoothening the output of the power of the WEC there is an application of BESS. Back to back converters and controllers for BESS are integrated and are generally used to assimilate WEC system into power grid [36-38]. Capacitor charging/discharging with in power conditioner brought the instantaneous power flow balancing in back to back converters. Thus, in WEC, active power is retained along with adequate power quality using BESS.

\section{Using BESS in scheduling}

For achieving system load shifting from daily peak to lows, BESS is used. MOPF (Multi-period optimal power flow) simulations face longer time consuming constraints. This creates practical limitations to the battery scheduling method. The extent of the system which can be simulated also suffers drawbacks, because of the relationship between the MOPF time intricacy and the size of the system being nonlinear [40-41].

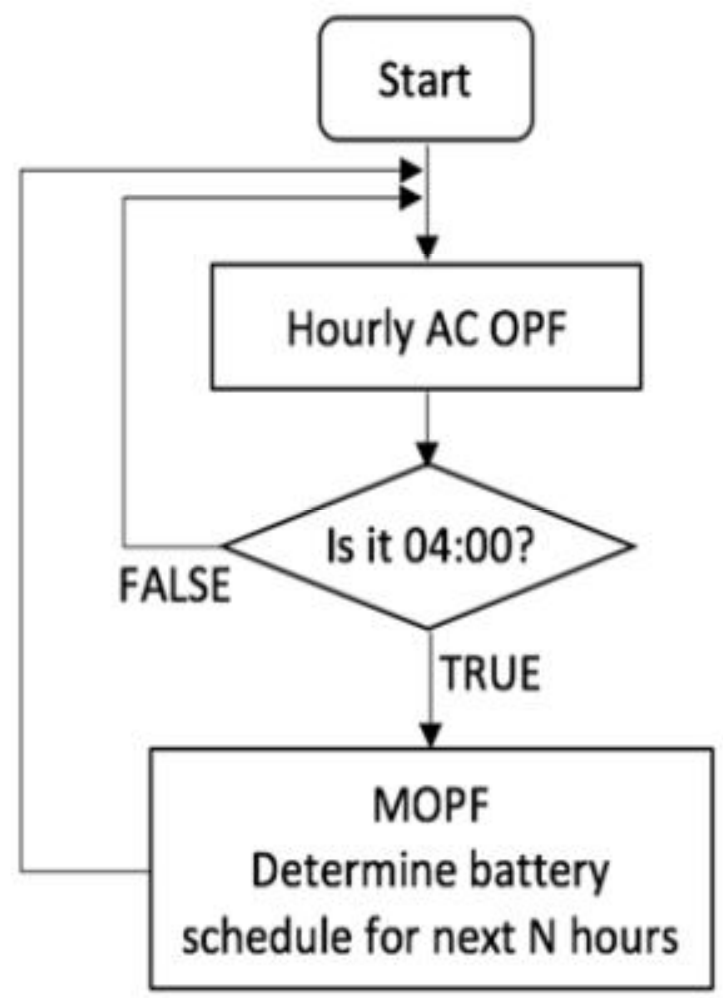

Figure 2: Battery scheduling flowchart [39]

Block diagram of system is projected with STATCOM as shown in figure 2. 


\section{Using Double Buck-boost DC/DC converter}

The implementation of double BUCK- BOOST DC/DC converters ensure a power bi-directional power transmission control circuit. Proficient systems like fuzzy logic, neural network [42-45] are lately functional to detect and contain the pitfalls of conventional controller. Aditya et al [45] applied BESS to a reheat thermal system which was interconnected to control load frequency. The discharging and charging maneuver of battery and super capacitor is controlled by the systematic circuit, and the high quality DC bus voltage control of PV system is realized [46-47]. An important role is played by energy storage converters in hybrid energy storage systems. The main application of BESS is the operation in uninterruptible power supply systems for systems involving emergency and communication purpose.

\section{BESS for Load frequency control (LFC)}

Lim et al [48] has anticipated a vigorous decentralized load frequency controller which is created on the basis of RiccatiEquation approach.

Wind turbine, photovoltaic power generators and other such renewable sources may lead to power system instability situation sometimes due to their output distortions. BESS are hence considered as the counter measure for such issues. The output of PV system as shown in fig .3, depends on the fluctuating weather conditions and the natural surroundings, which affects largely in the power output leading to frequency instability of the grid [49-51].

It is obligatory to develop balance in the charge across each cell in battery pack to boost the effective capacity [52-54], augment life time [55], and avoid thermal run-away [56-58]. Nonetheless, accessible systems are loss and can capably reduce the life span of the cells under assured situations [57$58]$.

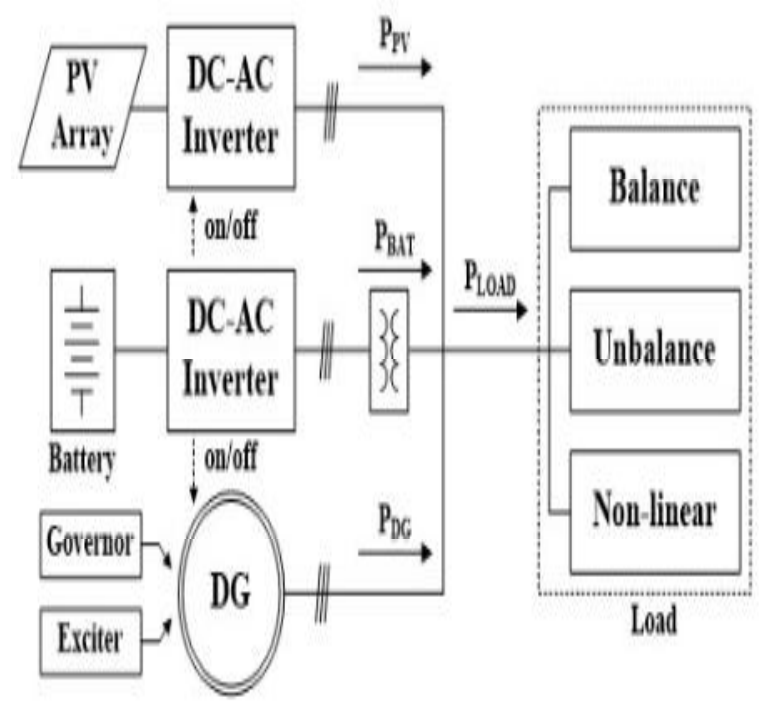

Figure 3: Standalone micro grid configuration [59]

\section{Other applications}

Superconducting magnetic energy storage (SCMES) and BESS are applicable in order to help with area and frequency control [59], regulation [60], greater transmission capacity [61], and better power quality [62-65]. It is observed that flywheel energy storage (FES) is appropriate for mitigating problems that deal with dynamic and transient stability [66-67], voltage regulation [68-69], and majorly improvement in power quality [70-71]. BESS has also been worked upon in the application as PVCF [72-76]. Although there is no different way to smoothen the PV output, still area of moving-average-based ramp-rate control is being explored [77-79]. Also, in load forecasting area, MAS (Multi-Agent System) been used which provides with power simulation, utility based micro grid, easy fault detection and an active distribution network system [80-82].

\section{HYBRID ENERGY STORAGE SYSTEM}

Because of technological advancements internationally and further progress on the WPGS (wind power generating system) [83-86], reduction in cost of generation from it has been observed. Generating electricity from the FC (fuel cell) is advantageous as it provides high efficiency; less polluting, easy installation and the heat and water waste can be reused because it consumes variety of fuels [86-91]. Adequate amount of electricity can be generated using large PV arrays in order to supply isolated load or a utility grid using dc-ac converters [92-94].

\section{Flywheel energy storage system (FESS)}

FESS has higher storage energy density, exchange of power within the system as well as greater conversion efficiency with a prolonged non- polluting design [95]. The FESS is able to provide a short-lived storage in order to filter power fluctuations by integrating the remote power systems working on WTGs into the weak grid [96-97].

\section{Other Integrated generation systems}

Aqua electrolyzes have been used in order to contain the issue of generating energy from the WTGs [98-106]. In [107-108] a single recurrent neural network (RNN) has been used to assess the energy performance in the long run which integrates wind and photovoltaic systems which consists of double diesel groups and BESS. Ceraolo et al. [109] created a mathematical model of BESS and represented it in [110112], which led to the rising of the question that whether their control method depends on the mathematical model or not [113-115]. Various kinds of RNN techniques for the modeling of intricate time-dependent phenomenon have been worked upon [116-118].

\section{CONCLUSION}

Grid stabilization has turned out to be a frequent concern all over the world with the increase in incursion of natural energy generation systems. The usage of renewable sources in the power grid to provide supply is escalating due to their non polluting, environment friendly nature. The availability of these resources in abundance has triggered its usage with BESS to contain power quality issues and improving reliability. The crux in case of renewable energy sources lies 
in the fact that intermittent power output is provided, such that the BESS has to be managed and used, and hence the combination of wind and solar photovoltaic could be driven to the loads as per the hourly forecasting considering the constraints regarding the SOC in order to avoid deep discharge. Hence, this has led to the shift in trends towards hybrid energy storage systems keeping in view the intermittent nature of renewable energy sources to increase the system reliability. BESS plays a vital role in further enhancing the reliability in addition to improvement in power quality of a distribution network without and with renewable energy sources.

\section{REFERENCES}

[1] G. Martin, "Renewable energy gets the "green" light in Chicago", IEEE Power and Energy Magazine, Vol. 1, No. 6, pp: 34-39, Nov.-Dec. 2003.

https://doi.org/10.1109/MPAE.2003.1243961

[2] Oudalov, D. Chartouni, C. Ohler, and G. Linhofer, "Value analysis of battery energy storage applications in power systems," in Proc. 2nd IEEE PES Power Systems Conference and Exposition, Atlanta, USA, 2006.

https://doi.org/10.1109/PSCE.2006.296284

[3] Divya, Jacob Ostergaard. "Battery Energy Storage Technology for Power Systems-an Overview,' Electric Power Systems Research ,2009, 79(4) , pp.511-520

https://doi.org/10.1016/j.epsr.2008.09.017

[4] J. T. Bialasiewicz. "Renewable Energy Systems With Photovoltaic Power Generators: Operation and Modeling", IEEE Transactions on Industrial Electronics, Vol. 55, No. 7, pp: 2752-2758, Jul. 2008.

https://doi.org/10.1109/TIE.2008.920583

[5] R. Karki, R. Billinton, "Reliability/cost implications of $P V$ and wind energy utilization in small isolated power systems", IEEE Transactions on Energy Conversion, Vol. 16, No. pp: 368-373, 4, Dec. 2001.

https://doi.org/10.1109/60.969477

[6] Divya, Jacob Ostergaard. "Battery Energy Storage Technology for Power Systems-an Overview," Electric Power Systems Research ,2009, 79(4) , pp.511-520

https://doi.org/10.1016/j.epsr.2008.09.017

[7] K. Iba, R. deta, K. Suzuki. "Analysis and Operational Records of NAS Battery," Universities Power Engineering Conference, 2006: 491 - 495

https://doi.org/10.1109/UPEC.2006.367526

[8] Kamibayashi, Nichols, Oshima. "Development Update of NAS battery," Transmission and Distribution Conference and Exhibition, 2002 ,3, pp.1664 - 1668

[9] C.L. Kana, M. Thamodharan, A. Wolf, "System management of a wind-energy converter", IEEE Transactions on Power Electronics, Vol.16, No. 3, pp. 375381, May 2001.

https://doi.org/10.1109/63.923770

[10] M. Harfman-Todorovic, M. Chellappan, L. Palma, P. Enjeti, "The role of supercapacitors in designing fuel cell powered portable applications",IEEE Power Electronics Specialists Conference, pp: 2465-2472, Jun.2008.

https://doi.org/10.1109/PESC.2008.4592311

[11] J. McDowall, "Conventional battery technologiespresent and future"IEEE Power Engineering Society Summer Meeting, Vol. 3 16-20, pp.1538-1540, July 2000.

[12] K. Yoshimoto, T. Nanahara, G. Koshimizu and Y. Uchida, "New Control Strategy for Regulating State-ofCharge of a Battery in Hybrid Wind Power/Battery Energy Storage System", IEEE Power Systems Conference and Exposition PES, pp. 1244-1251, 2006.

https://doi.org/10.1109/PSCE.2006.296485

[13] S. Duryea, S. Islam, W. Lawrance, “A battery management system for stand-alone photovoltaic energy systems", IEEE Industry Applications Magazine, Vol. 7, No. 3, pp: 67-72, May-Jun. 2001.

https://doi.org/10.1109/2943.922452

[14] R. F. Nelson, "Power requirements for batteries in hybrid electric vehicles", Journal of Power Sources, Vol. 91, No. 1, pp. 2-26, Nov.2000.

https://doi.org/10.1016/S0378-7753(00)00483-3

[15] W. Lhomme, P. Delarue, P. Barrade, A. Bouscayrol and A. Rufer,"Design and Control of a supercapacitor storage system for traction applications", Industry Applications Conference Fourtieth IAS Annual Meeting, Vol. 3, 2-6, pp. 2013-2020, Oct. 2005.

[16] A. Rufer and P. Barrade, "A Supercapacitor-based Energy-Storage System for Elevators with Soft Commutated Interface", IEEE Transactions on Industry Applications, Vol. 38, No. 5, pp. 1151-1159,Sept.-Oct. 2002. https://doi.org/10.1109/TIA.2002.803021

[17] M. B. Camara, H. Gualous, F. Gustin and A. Berthon, "Design and New Control of DC/DC Converters to Share Energy Between Supercapacitors and Batteries in Hybrid Vehicle", IEEE Transactions on Vehicular Technology, Vol. 57, No. 5, pp: 2721-2735, 2008.

https://doi.org/10.1109/TVT.2008.915491

[18] H. Yoo, S.-K. Sul, Y. Park and J. Jeong, "System Integration and Power-Flow Management for a Series Hybrid Electric Vehicle Using Supercapacitors and Batteries", IEEE Transactions on Industry Applications, Vol. 44, No. 1, pp. 108-114, Jan.-Feb. 2008.

https://doi.org/10.1109/TIA.2007.912749

[19] P. B. Jones, J. B. Lakeman, G. O. Mepsted, and J. M. Moore, "A hybrid power source for pulse power applications", J. Power Sources, Vol. 80, No. 1-2, pp. $242-$ 247, Jul. 1999.

https://doi.org/10.1016/S0378-7753(99)00074-9

[20] L. Gao, Z. Jiang and R. A. Dougal, "An actively controlled fuel cell/battery hybrid to meet pulsed power demands", J. Power Sources, Vol. 130, No. 2, pp. 202-207, May 2004.

https://doi.org/10.1016/j.jpowsour.2003.12.052

[21]Z. Jiang, L. Gao, and R. A. Dougal, "Design and experimental tests of control strategies for active hybrid fuel cell/battery powerr sources", J. Power Sources, Vol. 130, No. 1, pp. 163-171, May 2004.

https://doi.org/10.1016/j.jpowsour.2003.12.019

[22] L. Gao, R. A. Dougal, S. Liu, "Active power sharing in hybrid battery/capacitor power sources", IEEE 
Applied Power Electronics Conference and Exposition, Vol. 1, 9-13, pp: 497-503, 2003.

[23]Z. Jiang, L. Gao, and R. A. Dougal, "Design and experimental tests of control strategies for active hybrid fuel cell/battery powerr sources", J.Power Sources, Vol. 130, No. 1, pp. 163-171, May 2004.

https://doi.org/10.1016/j.jpowsour.2003.12.019

[24]Z. Jiang, R. A. Dougal, "Control strategies for active power sharing in a fuel-cell-powered battery-charging station", IEEE Transactions on Industry Applications", Vol. 40, No. 3, pp: 917-924, May-Jun. 2004.

https://doi.org/10.1109/TIA.2004.827467

[25] P. Thounthong, S. Rael, B. Davat, "Control Strategy of Fuel Cell and Supercapacitors Association for a Distributed Generation System", IEEE Transactions on Industrial Electronics, Vol. 54, No. 6, pp:3225-3233, Dec. 2007. https://doi.org/10.1109/TIE.2007.896477

[26] S. M. Lukic, J. Cao, R. C. Bansal, F. Rodriguez, A. Emadi, "Energy Storage Systems for Automotive Applications", IEEE Transactions on Industrial Electronics, Vol. 55, No. 6, pp: 2258-2267, Jun. 2008

https://doi.org/10.1109/TIE.2008.918390

[27] P. F. Ribeiro, B. K. Johnson, M. L. Crow, A. Arsoy, and Y. Liu, "Energy storage systems for advanced power applications," Proc. IEEE, vol. 89, no. 12, pp. 1744-1756, Dec. 2001. https://doi.org/10.1109/5.975900

[28] A. Rufer and P. Barrade, "A supercapacitor-based energy-storage system for elevators with soft commutated interface," IEEE Trans. Ind. Appl.,vol. 38, no. 5, pp. 1151-1159, Sep./Oct. 2002.

https://doi.org/10.1109/TIA.2002.803021

[29]U. Kohler, J. Kumpers, and M. Ullrich, "High performance nickel-metal hydride and lithium-ion batteries," J. Power Sources, vol. 105, no. 2, pp. 139-144, Mar. 2002.

https://doi.org/10.1016/S0378-7753(01)00932-6

[30] P. W. Hammond, "A new approach to enhance power quality for medium voltage ac drives," IEEE Trans. Ind. Appl., vol. 33, no. 1, pp. 202-208, Jan./Feb. 1997.

https://doi.org/10.1109/28.567113

[31] R. H. Osman, "A medium-voltage drive utilizing series-cell multilevel topology for outstanding power quality," in Conf. Rec. IEEE IAS Annual Meet., 1999, vol. 4, pp. 2662-2669.

[32] H. Akagi, S. Inoue, and T. Yoshii, "Control and performance of a transformerless cascade PWM STATCOM with star configuration,"IEEE Trans. Ind. Appl., vol. 43, no. 4, pp. 1041-1049, Jul./Aug.2007.

https://doi.org/10.1109/TIA.2007.900487

[33] L. Maharjan, T. Yoshii, S. Inoue, and H. Akagi, "A transformerless energy storage system based on a cascade multilevel PWM converter with star configuration," IEEE Trans. Ind. Appl., vol. 44, no. 5, pp. 1621-1630, Sep./Oct. 2008.

https://doi.org/10.1109/TIA.2008.2002180

[34] S. Piller, M. Perrin, and A. Jossen, "Methods for state-of-charge determination and their applications," J. Power Sources, vol. 96, no. 1, pp. 113-120, Jun. 2001. https://doi.org/10.1016/S0378-7753(01)00560-2
[35] L. M. Tolbert, F. Z. Peng, and T. G. Habetler, "Multilevel converters for large electric drives," IEEE Trans. Ind. Appl., vol. 35, no. 1, pp. 36-44, Jan./Feb. 1999. https://doi.org/10.1109/28.740843

[36] J. J. C. Kopera, "Inside the Nickel Metal Hydride Battery". Orion, MI: Cobasys, Jun. 2004.

[37] Q. Song, W. Liu, Z. Yuan, W. Wei, and Y. Chen, "DC voltage balancing technique using multi-pulse optimal PWM for cascade H-bridge inverters based STATCOM," in Proc. IEEE PESC, 2004, vol. 6, pp. 47684772.

[38] D. Soto and T. C. Green, "A dc link capacitor voltages control strategy for a PWM cascade STATCOM," in Proc. IEEE PESC, 2005, pp. 2251-2256.

[39] H. Plinnder, M. E. C. Damen, and F, Gardner, "Linear PM generator system for wave energy conversion in AWS," IEEE Trans. on Energy Conversion, vol. 19, no. 3, pp. 583-589, Sept. 2004.

https://doi.org/10.1109/TEC.2004.827717

[40] P.R.M. Brooking, and M.A. Mueller, "Power conditioning of the output from a linear vernier hybrid permanent magnet generator for use in direct ave energy converters," IEE Proc.-Gener. Transm. Distrib., vol. 152, no. 5, pp. 673-681, Sep. 2005.

https://doi.org/10.1049/ip-gtd:20045134

[41] B. Das, and B. C. Pal, "Voltage control performance of AWS connected for grid operation," IEEE Trans. on Energy Conversion, vol. 21, no. 2, pp. 353-360, June, 2006. https://doi.org/10.1109/TEC.2006.874220

[42] Yang Z, Shen C, Zhang L, Crow M.L, Atcitty $S$, "Integration of a StatCom and Battery Energy Storage," IEEE Transactions on Power Systems, Vol 16, Issue 2,pp:254 - 260. May 2001.

https://doi.org/10.1109/59.918295

[43] Kobayashi K., Goto M., Wu K,"Power system stability improvement by energy storage type STATCOM," Power Tech Conference Proceedings, IEEE Bologna, 2003:2-7.

[44] British Patroleum;, "BP Statistical Review of World Energy 2011," 2012.

[45] Lim, K. Y, Wang, Y and Zhou, R, "Robust decentrali9.":d load frequency control of multi- area poor systems," iEE Generation, Tram mission and Distribution, Vol. 143, issue 5, pp. 377-386, Sep .1996 .

https://doi.org/10.1049/ip-gtd:19960452

[46] Nijhawan P, Oberoi A.S., "An innovative design of solar wind hybrid system" International journal of advanced trends in computer science and engineering, vol.8, no.2, pp:203-207, 2019.

https://doi.org/10.30534/ijatcse/2019/15822019

[47] Nijhawan P, Oberoi A.S., Singh B, "A novel design for a solar PV-wind hybrid system to improvise renewable energy harnessing-a theoretical study on Indian sub continent," International journal of engineering and technology, vol.10, no.4, pp 1112-1118, 2018

[48] Rengarajan,N., Ra vichandran, C.S. and Palani, S, "Artificial Neural Network based design of governor controller," Amdemic Open internet Journal, Vol. 2 0, 2007. 
[49] Umrao, R. and Chattrved $\square$ D.K, "Load frequency control using polar fuzzy controller," Proc. TENCON 2010 iEEE Region 10 Conforence, pp. 557-562, Nov. 2010 . [50] Sundaram, VS. and Jayabarathi, T, "Load Frequency Control using PID tuned ANN controller in power system," Proc. International Conforence on Electriml Energy Systems (iC EES), 2011, pp. 2 69-2 74, Jan. 2011

[51] Aditya,S.K. and Das, D, " Battery energy storage for load frequency control of an interconnected power system," Electric Power Systems Research, Vol. 58, issue 3, pp. 179-185, July 2001.

[52] N. Kawakami, Y. Iijima, Y. Sakanaka, M. Fukuhara, K. Ogawa,M. Bando, T. Matsuda, "Development and field experiences of NAS battery Inverter for Power Stabilization of a 51 MW Wind Farm," The 20 I 0 International Power Electronics Conference,pp.IS37-IS41, June 2010.

[53] T. Tanaka, I. Tominaga, N. Kawakami, "Development of high efficiency PCS for storage batteries, " 2011 Japan Industry Application Society Conference Record, pp.1-421 1-422, September 2011. (in Japanese)

[54] H. Li, Y. Iijima, N. Kawakami, "Development of Power Conditioning System (PCS) for Battery Energy Storage Systems," the 5th Annual International Energy Conversion Congress and Exhibition for the Asia/Pacific region (ECCE Asia 2013), pp.1295 -1299, 2013.

[55] H. Akagi, "Classification, Terminology, and Application of the Modular Multilevel Cascade Converter (MMCC), " IEEE Transactions on Power Electronics, vo1.26, No. 11, pp.3119-3130,2011.

[56] 1. Maharjan, T. Yamagishi, H. Akagi, "Active-Power Control of Individual Converter Cells for a Battery Energy Storage System Based on a Multilevel Cascade PWM Converter," IEEE Transactions on Power Electronics, vo1.27, No.3, pp.1 099-11 07,2012

https://doi.org/10.1109/TPEL.2010.2059045

[57] L. Mahar:jan, S. Inoue, H. Aakagi, 1. Asakura, "Stateof-Charge(SOC)-Balancing Control of a Battery Energy Storage System Based on a Cascade PWM Converter, " IEEE Transactions on Power Electronics, Vo1.24, No.6, pp.162S-1636, June 2009.

https://doi.org/10.1109/TPEL.2009.2014868

[58] 1. Maharjan, T. Yamagishi, H. Aakagi, J. Asakura, "FaultTolerant Operation of a Battery-Energy-Storage System Based on a Multilevel Cascade PWM Converter, " IEEE Transactions on Power Electronics, vol. 27, No.3, pp. 1099-1107, March 2012

[59] N. Kawakami, S. Ota, H. Kon, S. Konno, H. Akagi, H.Kobayashi, N. Okada, "Development of a 500-kW Modular Multievel Cascade Converter for Battery Energy Storage systems, " IEEE Energy Conversion Congress \& Expo (ECCE 2013), pp.3375 -33SI, 2013

[60] J. Cao, N. Schofield, and A. Emadi, "Battery balancing methods: A comprehensive review," Vehicle Power and Propulsion Conference, 2008. VPPC '08. IEEE, pp. 1-6, 3-5 Sept. 20082008.

[61] M. Uno and K. Tanaka, "Influence of HighFrequency Charge-Discharge Cycling Induced by Cell Voltage Equalizers on the Life Performance of Lithium-
Ion Cells," Vehicular Technology, IEEE Transactions on,vol. 60, pp. 1505-1515, 2011.

[62] R. F. Nelson and M. A. Kepros, "AC ripple effects on VRLA batteries in float applications," Battery Conference on Applications and Advances, 1999. The Fourteenth Annual, pp. 281-289, 19991999.

https://doi.org/10.1109/BCAA.1999.796005

[63] L. Maharjan, S. Inoue, and H. Akagi, "A Transformer less Energy Storage System Based on a Cascade Multilevel PWM Converter With Star Configuration,"Industry Applications, IEEE Transactions on ,vol.44, no.5, pp.1621,1630, Sept.-Oct. 2008

https://doi.org/10.1109/TIA.2008.2002180

[64] J. Eyer, "Energy storage for the electricity grid: Benefits and market potential assessment guide, a study for the DOE energy storage systems program," Sandia National Lab, Rep. SAND2010-0815, Feb. 2010.

[65] P. F. Ribeiro, B. K. Johnson, M. L. Crow, A. Arsoy, and Y. Liu, "Energy storage systems for advanced power applications," Proc. IEEE, vol. 89, no. 12, pp. 1744-1756, Dec. 2001, doi: 10.1109/5.975900.

[66] V. Karasik, K. Dixon, C. Weber, B. Batchelder, G. Campbell, and P. Ribeiro, "SMES for power utility applications: A review of technical and cost considerations," IEEE Trans. Appl. Supercond., vol. 9, no. 2, pp. 541-546, Jun. 1999, doi: 10.1109/77.783354.

[67] D. Lieurance, F. Kimball, C. Rix, and C. Luongo, "Design and cost studies for small scale superconducting magnetic energy storage (SMES) systems," IEEE Trans. Appl. Supercond., vol. 5, no. 2, pp. 350-353, Jun.1995, doi: 10.1109/77.402561.

[68] J. McDowall, "Conventional battery technologiespresent and future," in Proc. IEEE PES Gener. Meeting, Jul. 27-31, 2010, pp. 1538-1540.

[69] W. V. Hassenzahl, "Capacitors for Electric Utility Energy Storage, " Electric Electric Power Research Institute, Rep. WO 8812, 1997.

[70] Kumar R, Nijhawan P, Saxena S., "A review of custom power devices for power quality improvement of distribution network with arc furnace," International journal of advanced trends in computer science and engineering, vol.8, no.2, pp:224-230, 2019.

[71] R. Boom and H. Peterson, "Superconductive energy storage for power systems," IEEE Trans. Magn., vol. M-8, no. 3, pp. 701-703, Sep. 1972, doi: 10.1109/TMAG.1972.1067425.

[72] R. F. Giese, "Progress toward high temperature superconducting magnetic energy storage (SMES) systems-A second look," Argonne National Lab Report, 1998.

[73] I. D. Hassan, R. M. Bucci, and K. T. Swe, "400 MW SMES power conditioning system development and simulation," Trans. Power Electron.,vol. 8, pp. 237-249, Jul. 1993.

https://doi.org/10.1109/63.233279

[74] Q. Jiang and M. F. Conlon, "The power regulation of a PWM type superconducting magnetic energy storage unit," IEEE Trans. Energy Convers., vol. 11, no. 1, pp. 168174, Mar. 1996. 
[75] W. R. Lachs and D. Sutanto, "Battery storage plant within large load centers," IEEE Trans. Power Syst., vol. 7, no. 2, pp. 762-769, May 1992.

[76] M. A. Casacca, M. R. Capobianco, and Z. M. Salameh, "Lead-acid battery storage configurations for improved available capacity," IEEE Trans.Energy Convers., vol. 11, no. 1, pp. 139-145, Mar. 1996.

https://doi.org/10.1109/60.486588

[77] N. W. Miller et al., "Design and commissioning of a 5 MVA, 2.5 MWh battery energy storage," in Proc. IEEE Power Eng. Soc. Transm. Distrib.Conf., 1996, pp. 339-345.

[78] N. Abi-Samra, C. Neft, A. Sundaram, andW. Malcolm, "The distribution system dynamic voltage restorer and its applications at industrial facilities with sensitive loads," in Proc. 8th Int. Power Qual. Solutions, Long Beach, CA, USA, Sep. 9-15, 1995.

[79] L. Xiangjun, H. Dong, and L. Xiaokang, "Battery energy storage station(BESS)-based smoothing control of photovoltaic (PV) and wind power generation fluctuations," IEEE Trans. Sustain. Energy, vol. 4, no. 2,pp. 464-473, Apr. 2013.

[80] M. J. E. Alam, K. M. Muttaqi, and D. Sutanto, "A novel approach for ramp-rate control of solar PV using energy storage to mitigate output fluctuations caused by cloud passing," IEEE Trans. Energy Convers., vol. 29, no. 2, pp. 507-518, Apr. 2013.

[81] S. A. Abdelrazek, S. Kamalasadan, and J. Enslin, "An approach for control of battery energy storage management systems considering multiple functions," in Proc. IEEE PES Gener. Meeting, Jul. 27-31, 2014, pp. 1-5.

[82] S. Abdelrazek and S. Kamalasadan, "Integrated control of battery energy storage management system considering PV capacity firming and energy time shift applications," in Proc. IEEE Ind. Appl. Soc. Annu. Meeting, Oct. 5-9, 2014, pp. 1-7.

[83] S. G. Tesfahunegn, Ø. Ulleberg, P. J. Vie, and T. M. Undeland, "PV fluctuation balancing using hydrogen storage-A smoothing method for integration of PV generation into the utility grid," Energy Procedia,vol. 12, pp. 1015-1022, 2011.

[84] N. A. Musa, M. Z. M. Yusoff, R. Ismail and Y. Yusoff, "Issues and challenges of forensics analysis of agents' behavior in multi-agent systems: A critical review," 2015 International Symposium on Agents, Multi-Agent Systems and Robotics (ISAMSR), Putrajaya, 2015, pp. 122-125.

[85] J.T. Alt, M.D. Anderson and R.G. Jungst, "Assessment of Utility side cost savings from battery energy storage," IEEE Trans. Power Systems,vol. 13, no.3, pp. 1112-1120, 1997.

[86] K. Iba, R. deta, K. Suzuki. "Analysis and Operational Records of NAS Battery," Universities Power Engineering Conference, 2006: 491 - 495

[87] Kamibayashi, Nichols, Oshima. "Development Update of NAS battery," Transmission and Distribution Conference and Exhibition, 2002 ,3, pp.1664 - 1668

[88] P. Wang and R. Billinton, "Reliability benefit analysis of adding WTG to a distribution system," IEEE Trans. Energy Convers., vol. 16, no. 2,pp. 134-139, Jun. 2001. https://doi.org/10.1109/60.921464
[89] N. Kodama, T. Matsuzaka, and N. Inomata,"The power variation control of a wind generator by using probabilistic optimal control," Trans. Inst.Elect. Eng. Japan, vol. 121-B, no. 1, pp. 22-30, 2001.

[90] P. M. Anderson and A. A. Fouad, Power System Control and Stability.Ames, IA: Iowa State Univ. Press, 1977.

[91]L. Gao, R. A. Dougal, and S. Liu, "Power enhancement of an actively controlled battery/ultracapacitor hybrid," IEEE Trans. Power Electron.,vol. 20, no. 1, pp. 236-243, Jan. 2005.

[92] Y. H. Li, S. S. Choi, and S. Rajakaruna, "An analysis of the control and operation of a solid oxide fuel-cell power plant in an isolated system," IEEE Trans. Energy Convers., vol. 20, no. 2, pp. 381-387, Jun. 2005.

[93] X. J. Liu and C.W. Chan, "Control of a solid oxide fuel cell power plant in a grid-connected system," IEEE Trans. Energy Convers., to be published.

[94] T. F. Fuller and J. Newman, "Water and thermal management in solid polymer-electrolyte fuel cells," J. Electrochem. Soc., vol. 140, pp. 1218-1225, 1993.

[95] Y. H. Kim and S. S. Kim, "An electrical modeling and fuzzy logic control of a fuel cell generation system," IEEE Trans. Energy Convers., vol. 14,no. 2, pp. 239-244, Jun. 1999.

[96] K. Ro and S. Rahman, "Two-loop controller for maximizing performance of a grid-connected photovoltaic-fuel cell hybrid power plant," IEEE Trans. Energy Convers., vol. 13, no. 3, pp. 276-281, Sep. 1998.

[97]D. J. Hall and R. G. Colclaser, "Transient modeling and simulation of a tubular solid oxide fuel cell," IEEE Trans. Energy Convers., vol. 14, no. 3,pp. 749-753, Sep. 1999.

https://doi.org/10.1109/60.790946

[98] H. Matsuo and F. Kurokawa, "Novel solar cell power supply system using bidirectional dc-dc converter," in Proc. IEEE Power Electron. Spec.Conf.(PESC), Cambridge, MA, Jun. 1982, pp. 14-19.

[99] R. S.Weissbach, G. G. Karady, and R. G. Farmer, "Dynamic voltage compensation on distribution feeders using flywheel energy storage," IEEE Trans. Power Del., vol. 14, no. 2, pp. 465-471, Apr. 1999.

[100] N. Hatziargyrio, M. Donnelly, M. Takasaki et al., "Modeling New Forms of Generation and Storage," CIGRE TF.01.10, Fifth draft, Jun. 2000.

[101] T. Senjyu, T. Nakaji, K. Uezato, and T. Funabashi, "A hybrid power system using alternative energy facilities in isolated island," IEEE Trans. Energy Convers., vol. 20, no. 2, pp. 406-414, Jun. 2005.

[102] F. Valenciaga, P. F. Puleston, and P. E. Battaiotto, "Power control of a solar/wind generation system without wind measurement: A passivity/ sliding mode approach," IEEE Trans. Energy Convers., vol. 18, no. 4,pp. 501-507, Dec. 2003.

[103] K. Rajashekara, "Hybrid fuel-cell strategies for clean power generation,'IEEE Trans. Ind. Appl., vol. 41, no. 3, pp. 682-689, May/Jun. 2005.

[104] F. Valenciaga and P. F. Puleston, "Supervisor control for a stand-alone hybrid generation system using 
wind and photovoltaic energy," IEEE Trans. Energy Convers., vol. 20, no. 2, pp. 398-405, Jun. 2005.

[105] E. Muljadi and H. E. McKenna, "Power quality issues in a hybrid power system," IEEE Trans. Ind. Appl., vol. 38, no. 3, pp. 803-809, May/Jun.2002.

[106] R. W. Wies, R. A. Johnson, A. N. Agrawal, and T. J. Chubb, "Simulink model for economic analysis and environmental impacts of a PV with diesel battery system for remote villages," IEEE Trans. Power Syst.,vol. 20, no. 2, pp. 692-700, May 2005.

[107] A. Emadi, S. S.Williamson, and A. Khaligh, "Power electronics intensive solutions for advanced electric, hybrid electric, and fuel cell vehicular power systems," IEEE Trans. Power Electron., vol. 21, no. 3, pp. 567-577, May 2006.

[108] Teleke, S.; Baran, M.E.; Bhattacharya, S.; Huang, A. Q.:Rule Based control of battery energy storage for dispatching intermittent renewable sources, IEEE Transaction on Sustainable Energy, vol. 1, N. 3, October 2010.

[109] Bonanno, F.; Capizzi, G.; Tina, M.: Long term energy performance forecasting of integrated generation systems by recurrent neural networks, Proceedings of IEEE ICCEP 2009, Capri, Italy, June 2009.

[110] Bonanno, F.; Capizzi, G.; Tina, M.: Recurrent neural networks based modeling and simulation of leadacid battery charge-discharge, IEEE Trans. On Energy Conversion.__ 26, NO. 2, June 2011.

[111] Ceraolo, M.: New dynamical models of lead-acid batteries,IEEE Trans. on Power Systems, vol. 15, N. 4, November 2000, pp. 1184-1190.

[112] Ceraolo, M.; Barsali, S.: Dynamical models of leadacid batteries: implementation issues, IEEE Trans. on Energy Convers., vol. 17, N. 1, March 2002, pp. 16-23.

https://doi.org/10.1109/60.986432

[113] Capizzi, G.; Bonanno, F.: Fuzzy Logic Based Energy Flows Management of Integrated Generation Systems.Advances in Intelligent Systems, edited by F.C. Morabito, IOS Press 1997 in the Series Frontiers in Artificial Intelligence Applications pp. 247-252.

[114] Capizzi, G.; Tina, M.: Long-Term Operation Optimization of Integrated Generation Systems by Fuzzy Logic-Based Management. Energy 2007 Volume 32, Issue 7, pp.1047-1054, Energy 2007,

[115] Capizzi, G.; Bonanno, F.; Napoli, C.: A Wavelet Based Prediction of Wind and Solar Energy for LongTerm Simulation of Integrated Generation Systems, Proceedings of IEEE SPEEDAM 2010,Pisa, Italy, June 2010.

[116] Williams R. and Zipser, D.: Experimental analysis of the real-time recurrent learning algorithm. Connection Science, Volume 1, n0 1, 1989, pp. 87-111.

[117] Williams R. and Zipser, D.: A learning algorithm for continually running fully recurrent neural networks. Neural Computation, Volume 1, Issue 2, 1989 pp. 270-280. [118] Haykin, S.: Neural networks: A comprehensive foundation, Prentice-Hall, Englewood Cliffs, 1999.

https://doi.org/10.1162/neco.1989.1.2.270 